ENTREPRENEURSHIP AND SUSTAINABILITY ISSUES

ISSN 2345-0282 (online) http://jssidoi.org/jesi/ 2019 Volume 7 Number 1 (September)

http://doi.org/10.9770/jesi.2019.7.1(50)
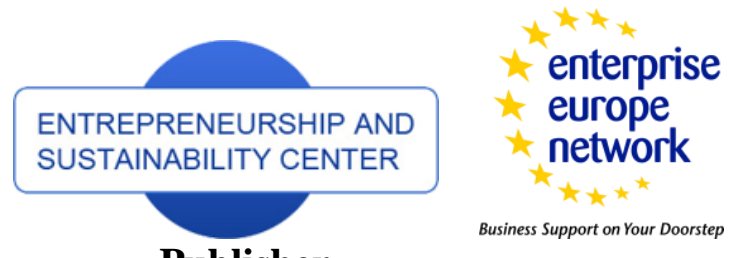

CASPA

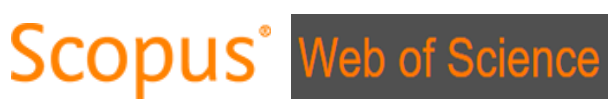

http://jssidoi.org/esc/home

I Clarivate

\title{
EVALUATION OF COMPETITIVENESS FACTORS OF INSURANCE COMPANIES*
}

\section{Gulzira Serikova $^{1}$, Yerkenazym Orynbassarova ${ }^{2}$, Svetlana Kuzgibekova $^{3}$, Zeinegul Yessymkhanova ${ }^{4}$, Galiya Tatiyeva $^{5}$, Ainura Omarova ${ }^{6}$}

\author{
1,2,3,4,6 Karaganda Economic University of Kazpotrebsoyuz, Akademicheskaya 9 street, Karaganda, Kazakhstan \\ ${ }^{5}$ Turan Astana, Dukenuly 29 Street, Astana, Kazakhstan
}

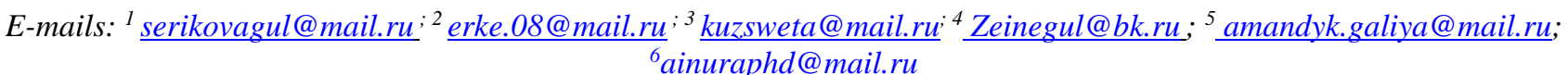

Received 15 February 2019; accepted 10 August 2019; published 30 September 2019

\begin{abstract}
The effective functioning of the insurance market is one of the internal factors of the progressive development of the domestic economy. The role of insurance is constantly increasing, because insurance reduces risks in all spheres of economic activity, guarantees the preservation of income and savings, provides the ability to use the available funds of the insurance fund as an additional source of investment. Comparative analysis of the concepts of competitiveness and existing methods of assessing the level of competitiveness suggests that the concept of competitiveness is perceived by many scientists, experts, is ambiguous, has a rather broad interpretation. At the present stage, in the conditions of integration, a study of the competitiveness of insurance companies is relevant. This article discusses the theoretical aspects of ensuring the competitiveness of insurance companies, in particular, gives a generalized description of the concept of competitiveness, considers a methodology for assessing the competitive advantages of insurance companies, identifies factors and basic conditions for its provision. Benefits of insurance organizations through a "polygon is competitive STI "demonstrates the competitive position of companies in the market of insurance uslug. On the basis of this methodology analyzes Kazakh activity of insurance companies, determined by their development problems and propose a set of measures aimed at solving problems that are fundamentally important for the successful operation of insurance companies.
\end{abstract}

Keywords: insurance; risk; assessment; competetiveness

Reference to this paper should be made as follows: Serikova, G.; Orynbassarova, Ye.; Kuzgibekova, S.; Yessymkhanova, Z.; Tatiyeva, G.; Omarova, A. 2019. Evaluation of competitiveness factors of insurance companies, Entrepreneurship and Sustainability Issues 7(1): 704713. http://doi.org/10.9770/jesi.2019.7.1(50)

\footnotetext{
* This research was supported by the project, which has received funding from the Kazakhstan Ministry of Education and Science under the grant of "Best teacher of the university - 2018"

http://edu.gov.kz/m/news/detail.php?ELEMENT_ID=11522
} 


\section{ENTREPRENEURSHIP AND SUSTAINABILITY ISSUES}

ISSN 2345-0282 (online) http://jssidoi.org/jesi/

2019 Volume 7 Number 1 (September)

http://doi.org/10.9770/jesi.2019.7.1(50)

JEL Classifications: G22, G32.

\section{Introduction}

The development of the insurance industry is influenced by a combination of macroeconomic and microeconomic factors, the conditions for economic integration and the consequences of the financial crisis. Under these conditions, the role and place of the national insurance market in an integration association to a certain extent depends on its ability to function effectively and to be competitive (Sembekov, Serikova 2017). Therefore, today it is relevant to assess the development of the insurance market in Kazakhstan in order to determine the prospects for its competitiveness. Criteria for assessing the competitive environment and competitive opportunities of insurance companies should be selected based on objective macroeconomic indicators, taking into account the influence of the microeconomic level of the activities of insurance companies (Sembekov, Serikova 2015). Competitiveness in the insurance sector in a market economy is a generalizing characteristic of the insurance industry, reflecting the level of efficiency of use of economic resources relative to the efficiency of use of economic resources by competitors (Vorotnikov 2016).

\section{Literature review}

According to some scientists, competitiveness is defined as "the ability to produce and consume goods and services in a competitive environment with goods and services produced in other countries, and the result of competition should be a rise in the standard of living of the population while observing international environmental standards" (Vorotnikov 2016).

It can be noted that the understanding of competitiveness lies in "finding the main characteristics of a state that gives its companies the opportunity to seek and maintain competitive advantages in certain areas, this is a search for competitive advantages in different countries" (Shekhovtseva 2015).

Quite interesting is the definition of competitiveness proposed by Michael Storper, who believes that the competitiveness of an economy is its ability to attract and retain firms with stable or growing market shares to continue their activities while maintaining or improving the standard of living of everyone who participates in this activity (Valisieva 2016).

The definition of the domestic academician U. Baimuratov (Baimuratov 2016) noted that the competitiveness of the national economy means the ability of the economic system to meet the reasonable material and spiritual needs of people in a competitive environment in domestic and foreign markets for goods and services in compliance with international environmental standards. Competitiveness is not an end in itself, but only a means of improving the quality of life (Porter 2016).

According to professor L. Blyakhman, "competitiveness is the ability to maintain and increase its share in the value added created in this segment of the world or national market of goods and services, the ability to develop and effectively use its competitive advantages" (Blyakman 2018, p.35).

Evaluation of the competitiveness of an organization can be carried out only among enterprises belonging to the same industry, or producing the same goods or services. The competitiveness of an organization largely depends on how well the firm can adapt to the changing conditions of competition in the market. In contrast to the competitiveness of a product, the competitiveness of an organization cannot be achieved in a short period of time. The competitiveness of the organization is achieved with a long and flawless work in the market. From this we 


\section{ENTREPRENEURSHIP AND SUSTAINABILITY ISSUES}

ISSN 2345-0282 (online) http://jssidoi.org/jesi/

2019 Volume 7 Number 1 (September)

http://doi.org/10.9770/jesi.2019.7.1(50)

can conclude that a company operating a longer period of time in the market has great competitive advantages over only entering the given market or operating for a short period of time on it. In other words, the competitiveness of an organization determines its competitive advantages. Competitive advantages, in turn, are divided into external and internal. The organization is not able to influence external factors, but internal factors are almost entirely controlled by the management of the organization, or rather, the organization's management has all the necessary conditions to control these factors. Achieving the internal competitive advantages of the organization is carried out by staff, with a special role assigned to the head.

\section{Methodology}

Based on the essential characteristics of this concept of competitiveness, we can draw the following conclusions: 1) competitiveness acts as the main effective tool of the national economy in raising the level and quality of life of the population;

2) competitiveness is characterized by a high level of development of scientific and technical potential based on high innovations;

3) the ability of national manufacturing enterprises to manufacture and supply goods and services to markets through the use of their competitive advantages that meet the requirements of consumers from foreign and domestic markets;

4) a high level of productive factors of production in the country, respectively, high productivity of resource use;

5) the country's ability to achieve high economic growth in the medium term and is characterized by a high level of social development and economic growth in the country in the long term;

6) competitiveness of an economy is its ability to withstand competition, to maintain stable or growing segments in the sales markets of the world, regional or national markets for goods and services.

To analyze the competitiveness of insurance companies, the most complete set of key factors is needed that influence the organizational, economic, and financial parameters that characterize its competitiveness. To assess the factors of competitiveness, we used the "polygon of competitiveness" method based on the use of inter-firm analysis proposed by V. Moshnov (Moshnov 2015).

Taking into account the specifics of the object of study, this method should be adjusted since the competitiveness of an insurance organization, as noted above, depends on the competitiveness of its financial and economic activities and the competitiveness of the insurance services provided by it.

Thus, the "polygon of competitiveness" in this perspective will consist not only of the competitiveness factors of the insurance service, but also of the financial and economic factors of the competitiveness of the insurance organization.

Evaluation of competitiveness in the form of a geometric figure, clearly characterizes the real competitive position of the insurance company in the insurance market. Moreover, the vectors of the axes of the polygon correspond to the number of financial and economic factors selected for analysis, the value of which improves with distance from its center (Zhuk 2015).

The generalized estimated parameter of competitiveness as a cumulative effect of all competitive advantages incorporated into the model is defined as the area of the polygon built on the axes vectors correlated with the indicators of the level of these competitive advantages.

In addition to the price of the service, the parameters that characterize its attractiveness for a client of a company are its properties that manifest themselves directly in contact with the insured at any stage of the insurance process: from sale to insurance payment. The results of this interaction should suit the insured, both in substance 


\section{ENTREPRENEURSHIP AND SUSTAINABILITY ISSUES}

ISSN 2345-0282 (online) http://jssidoi.org/jesi/ 2019 Volume 7 Number 1 (September) http://doi.org/10.9770/jesi.2019.7.1(50)

and in form. The parameters of insurance services assessed by the insured include the following financial factors of competitiveness: the size of insurance premiums; the variety of insurance products offered by the insurer; the level of insurance payments, suggesting an effective system of claims settlement (Moskaleva 2014).

The analyzed financial and economic factors include: a variety of insurance products (types of insurance), regional networks (number of branches), a sufficient amount of assets of an insurance organization, a sufficient amount of capital, reserves, the amount of insurance payments and insurance premiums. They fully allow to characterize the competitiveness of an insurance organization from the position of its financial and economic components (Kirillova 2016).

\section{Application functionality}

The competitiveness of the insurance organization, determined by the influence of factors or the relationship between them, is combinatorially great. This circumstance essentially characterizes the specificity of factors and imposes a number of limitations in the process of their study. The concept of "combinatorial" should be defined as the presence of any factors in the system of a variety of combinations of connections and variants of relations between them that can dynamically change their state.

Therefore, to study the most complete set of factors of competitiveness of insurance organizations, we turn to the main indicators of competitiveness (2019).

In economic theory, there are four main indicators characterizing the size of the insurance organization relative to the size of the market. These indicators include:

- the share of sales of the company in the market volume of sales;

- the share of the value of the assets of the company in the value of the assets of all firms operating in the market;

- the share of employees in the enterprise in the number of people employed in the production of this product;

- the share of value added at the enterprise in the amount of added value of all manufacturers operating on the market (Nabieva 2013).

In relation to the insurance market in domestic practice, only the first two indicators are used.

In modern studies on the competitiveness of organizations, concentration indicators are classified as follows:

1. Using absolute concentration indicators assess the number of enterprises in the market and market share per one company or group of companies.

2. Using relative indicators that assess the variability of market entities, uniform distribution of shares and the ratio of the sizes of individual entities to each other (Chernykh 2017).

The variety of methods for assessing the competitiveness of organizations is associated not only with the lack of a single terminological base, but also with the fact that competitiveness assessment is usually carried out in relation to various market entities. Moreover, each of the subjects is guided by its own assessment criteria, depending on the objectives pursued (Spletukhov 2015).

Since the assessment of the competitiveness of each of the compared insurance organizations can be interpreted through the area of geometric figures - polygons of competitiveness (SNC), then when conducting intercompany comparisons of competitive advantages for each insurance organization we get: 
$\mathrm{SH}_{\mathrm{ci}}=\frac{1}{2} \sin \alpha \mathrm{x}\left(\mathrm{K}_{1} \times \mathrm{K}_{2}+\mathrm{K}_{2} \times \mathrm{K}_{\mathrm{n}} \ldots+\mathrm{K}_{\mathrm{n}}+\mathrm{K}_{\mathrm{n}-1}\right.$

where: service);

$\mathrm{SH}_{\mathrm{ci}}$ - polygon area of competitiveness of an insurance organization (economic activity or insurance

$K_{1}-K_{2}$ - estimated parameters of competitive advantages included in the model.

$\mathrm{SH}_{\mathrm{ci}}$ for the factors analyzed in this article, the equation will be:

$\mathrm{SH}_{\mathrm{ci}}=\frac{1}{2} \sin \alpha \mathrm{x}\left(\mathrm{K}_{\mathrm{a}} \mathrm{x} \mathrm{K}_{\mathrm{c}}+\mathrm{K}_{\mathrm{r}} \mathrm{xK}_{\mathrm{pi}}+\mathrm{K}_{\mathrm{p}}+\mathrm{K}_{\mathrm{pr}}+\mathrm{K}_{\mathrm{pr}} \mathrm{x} \mathrm{K}_{\mathrm{p}}+\mathrm{K}_{\mathrm{p}} \mathrm{x} \mathrm{K}_{\mathrm{pr}}+\mathrm{K}_{\mathrm{pr}} \mathrm{x} \mathrm{K}_{\mathrm{reg}}\right)$

where:

$\mathrm{K}$ - indicative of competitive advantage, including:

$K_{a}$ - assets of the insurance organization;

$K_{c}$ - capital insurance organization;

$K_{r}$ - sufficiency of reserves of the insurance organization;

$K_{p i}$ - premiums of the insurance organization;

$K_{p}$ - the level of insurance payments;

$K_{p r}$ - variety of insurance products;

$K_{\text {reg }}-$ availability of regional networks.

In order to determine the competitiveness of the proposed method, we will analyze the insurance organizations operating in the general insurance industry, including: IC Eurasia, IC Victoria, NOMAD LIFE, and Halyk Bank of Kazakhstan "Halyk - Kazakhinstrakh", JSC "Life Insurance Company" Kazkommerts-Life "(subsidiary JSC" Kazkommertsbank "), JSC "Halyk-Life", JSC "IC Kazkommerts-Policy", JSC State Annuity Company JSC, IC JSC Kazakhmys, JSC StandardLife JSC based on statistical reports (2019).

The analysis of factors of competitiveness of the leading Kazakhstan insurers is based on official financial reporting data. Baseline data for analysis are presented in Table 1. As a baseline, indicators of financial and economic factors of the insurance company Standard-Life Insurance Company JSC were used.

Table 1. Baseline data for the calculation of the estimated indicators of the factors of competitiveness of insurance organizations for 2017

\begin{tabular}{|l|l|l|l|l|l|l|l|}
\hline Name of company & $\begin{array}{l}\text { Value of } \\
\text { assets }\end{array}$ & $\begin{array}{l}\text { Insurance } \\
\text { reserves } \\
\text { capital }\end{array}$ & $\begin{array}{l}\text { Amount of } \\
\text { insurance } \\
\text { payments } \\
\text { of } \\
\text { insurance } \\
\text { products }\end{array}$ & $\begin{array}{l}\text { A variety } \\
\text { premiums }\end{array}$ & $\begin{array}{l}\text { Regional } \\
\text { Networks }\end{array}$ \\
\hline JSC IC "Eurasia" & 202156320 & 86866537 & 112237363 & 23557557 & 27 & 48999187 & 13 \\
\hline JSC IC "Victoria" & 86388036 & 6139240 & 80082850 & 528491 & 16 & 4124197 & 12 \\
\hline JSC KIL "NOMAD LIFE" & 56945933 & 46428629 & 9055759 & 4335399 & 6 & 17411199 & 16 \\
\hline $\begin{array}{l}\text { JSC "Halyk Kazakh } \\
\text { Instrakh" }\end{array} 55487119$ & 20014994 & 29122972 & 8089633 & 26 & 36388290 & 18 \\
\hline $\begin{array}{l}\text { JSC "Company of life } \\
\text { insurance" "Kazkommerz - } \\
\text { Life" }\end{array}$ & 54773934 & 45706939 & 7085344 & 4865876 & 6 & 13441292 & 16 \\
\hline $\begin{array}{l}\text { JSC of Halyk bank of life } \\
\text { insurance "Halyk life" }\end{array}$ & 48400715 & 36346673 & 8768343 & 2487119 & 6 & 24431321 & 17 \\
\hline
\end{tabular}


ENTREPRENEURSHIP AND SUSTAINABILITY ISSUES

ISSN 2345-0282 (online) http://jssidoi.org/jesi/ 2019 Volume 7 Number 1 (September)

http://doi.org/10.9770/jesi.2019.7.1(50)

\begin{tabular}{|l|l|l|l|l|l|l|l|}
\hline $\begin{array}{l}\text { JSC IC "Kazkommerz } \\
\text { police" }\end{array}$ & 38275319 & 11959377 & 20995895 & 3316483 & 25 & 16331508 & 18 \\
\hline $\begin{array}{l}\text { JSC "State Annuity } \\
\text { Company " }\end{array}$ & 33500388 & 27328367 & 6043691 & 2088326 & 4 & 2113892 & 15 \\
\hline JSC IC "Kazakhmys" & 30996502 & 21614030 & 7941187 & 1930035 & 25 & 45026554 & 9 \\
\hline JSC "StandardLife" & 21060884 & 16945871 & 3716121 & 1105294 & 6 & 8432650 & 18 \\
\hline
\end{tabular}

Source: compiled by authors according to the source of National bank

The results of calculations of estimated indicators of factors of competitiveness of insurance companies are shown in table 2.

Table 2. Indicators of factors of competitiveness of insurance companies in Kazakhstan

\begin{tabular}{|l|l|l|l|l|l|l|l|l|}
\hline Name of insurance company & $\mathrm{Ka}$ & $\mathrm{Kr}$ & $\mathrm{Kc}$ & $\mathrm{Kp}$ & $\mathrm{Kpr}$ & Kpi & Kreg & SHci \\
\hline JSC IC "Eurasia" & 9,60 & 5,13 & 30,20 & 21,31 & 4,50 & 5,81 & 0,72 & 8,52 \\
\hline JSC IC "Victoria" & 4,10 & 0,36 & 21,55 & 0,48 & 2,67 & 0,49 & 0,67 & 0,20 \\
\hline JSC KIL "NOMAD LIFE" & 2,70 & 2,74 & 2,44 & 3,92 & 1,00 & 2,06 & 0,89 & 0,28 \\
\hline JSC "Halyk Kazakh Instrakh" & 2,63 & 1,18 & 7,84 & 7,32 & 4,33 & 4,32 & 1,00 & 1,09 \\
\hline $\begin{array}{l}\text { JSC "Company of life insurance" } \\
\text { "Kazkommerz -Life" }\end{array}$ & 2,60 & 2,70 & 1,91 & 4,40 & 1,00 & 1,59 & 0,89 & 0,24 \\
\hline $\begin{array}{l}\text { JSC of Halyk bank of life insurance } \\
\text { "Halyk life" }\end{array}$ & 2,30 & 2,14 & 2,36 & 2,25 & 1,00 & 2,90 & 0,94 & 0,20 \\
\hline JSC IC "Kazkommerz police" & 1,82 & 0,71 & 5,65 & 3,00 & 4,17 & 1,94 & 1,00 & 0,39 \\
\hline JSC "State Annuity Company " & 1,59 & 1,61 & 1,63 & 1,89 & 0,67 & 0,25 & 0,83 & 0,09 \\
\hline JSC IC "Kazakhmys" & 1,47 & 1,28 & 2,14 & 1,75 & 4,17 & 5,34 & 0,50 & 0,35 \\
\hline JSC "StandardLife" & 1,00 & 1,00 & 1,00 & 1,00 & 1,00 & 1,00 & 1,00 & 0,05 \\
\hline
\end{tabular}

The "polygon of competitiveness factors" constructed on the basis of the calculations made is presented in Figure 1. 


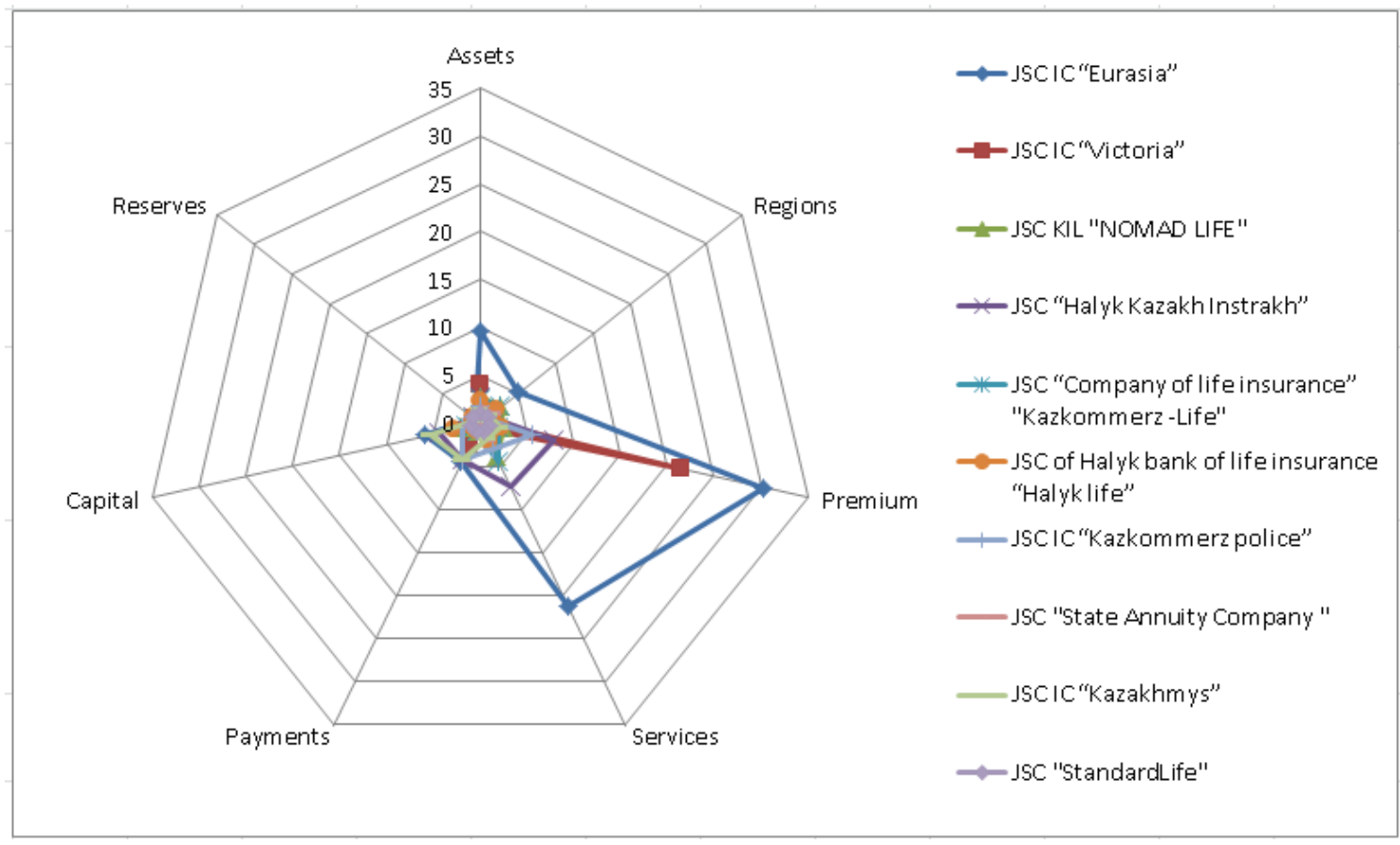

Figure 1. Polygon of competitiveness factors. Source: compiled by authors

Thus, as can be seen from Figure 1, the insurance market leaders are insurance companies: Eurasia Insurance Company JSC, Halyk-Kazakhinstrakh Insurance Company JSC People's Bank of Kazakhstan, Kazkommertsbank Insurance Company JSC (Kazkommertsbank JSC subsidiary). As we can from the Figure 1, these results is based on the following solutions:

- occupied market share,

- industry growth rate,

- intensity of competitive rivalry and others.

The degree of stability of the company's competitive position in the market is calculated using an indicator market share, the value of which should be determined and predicted. Market share is the ratio of the sales volume of a particular product of a given enterprise to the total sales volume of a given product carried out by all entities operating in this market. A company (company) can achieve competitive advantages and strengthen its position by:

- ensuring lower costs for the production and marketing of goods;

- ensuring the indispensability of the product through differentiation.

The competitiveness of which is, respectively: $8.52 ; 1.09$ and 0.39 . According to the figure 1 , these results had been accomplished. Summing up, it should be noted that the above method allows to explore not only the factors affecting the competitiveness of insurance companies, but also to assess the effects of their changes in the future, as well as their impact on the competitive position of companies in the insurance market.

Thus, the analysis of changes in the structure and growth dynamics of insurance premiums and payments allows us to draw the following conclusions: this sector of the economy is at a growth stage. At the same time, in the 
near medium term, we assume a slowdown in the growth rate of the insurance sector due to the fact that the economy of Kazakhstan began to recover gradually.

\section{Conclusions}

Our analysis shows that the level of competitiveness of Kazakhstan insurance companies is insufficient. The possibilities of insurance organizations are gradually increasing, but remain very limited so far. The previously adopted programs for the development of the insurance market remain unfulfilled, achieving the ratio of insurance premiums to GDP of up to $2 \%$ was assumed at the beginning of the second half of the last decade, but over the past 5 years, this indicator has not only not increased, but decreased.

Our analysed indicators show that in the near future insurance companies would be under tremendous pressure from other segments of the financial market (currency fluctuations, stock market volatility, license reviews and a sharp decline in the banking market). The falling incomes of the population and the unstable dynamics of the real sector also affect the situation in the insurance and reinsurance markets. It is obvious that national economies and insurance sectors, as integral parts, cannot develop independently of each other with different growth vectors. The state of the national economy affects the quality of insurance development, the demand for insurance services, and, accordingly, the development potential of the insurance market.

Competition of economic communities for attracting a taxpayer stimulates the application of similar approaches to the formation of tax systems within a particular community. At the same time, tax harmonization should not only preserve certain features of tax regulation, but should objectively aim at the medium term to lead to the complete standardization of tax systems and the procedure for levying taxes and fees.

Activization of insurance is possible only after the general revival of the economic situation. Further development of the insurance market will also largely depend on direct state support for the processes of integration of domestic insurers, the provision of a particularly favorable tax regime, improvement of business processes of insurance companies, namely the use of modern forms of insurance marketing, the active introduction of new insurance services and products

Thus, in our opinion, the practical implementation of our proposed set of measures and proposals for improving the activities of insurance companies in Kazakhstan will increase the competitiveness of the national insurance market.

\section{References}

Blyakman, L.S., Abisheva, A.A. 2018. Competitiveness: theory, methodology, practice. Almaty. 259p.

Baimuratov, U. 2016. Science of global economy. Almaty. 136p.

Chernykh, M.N., Azemsha, E.A. 2017. Methodology for determining the financial stability of an insurance company. Taxation, accounting and reporting in an insurance company, 4(17): 24-27.

Kirillova, N.V. 2016. Risk Management Systems in Insurance Organizations. World of the New Economy, 3(14): $116-123$. 


\section{ENTREPRENEURSHIP AND SUSTAINABILITY ISSUES}

ISSN 2345-0282 (online) http://jssidoi.org/jesi/ 2019 Volume 7 Number 1 (September)

http://doi.org/10.9770/jesi.2019.7.1(50)

Moshnov, V.A. 2015. A comprehensive assessment of the competitiveness of an enterprise. Corporate Management, 5(2): 122-133.

Moskaleva, E. G. 2014. Methodological approaches to the analysis of funds according to the financial statements of the insurance company. Economic analysis: theory and practice, 45(396): 50-61.

Nabieva, A. 2013. Insurance market of Kazakhstan: problems and development prospects. KAZENERGY Magazine, 1(56): 68-73, http://www.kazenergy.com

National Bank of the Republic of Kazakhstan. 2019. Current Status of the Insurance Sector of the Republic of Kazakhstan, http://www.nationalbank.kz.

Porter, M. 1993. International Competition. Moscow. 896p.

Porter, M. 2016. Competition. Moscow. Williams Publishing House. 608p.

Samiev, P.A. 2018. The structure and effectiveness of investments of insurers. Auditor, 10(31): 94-102.

Sembekov, A.K., Serikova, G.S. 2015. Factors and conditions of the competitiveness of the insurance market in the conditions of the EAEU integration. Karaganda. 168p.

Sembekov, A.K., Serikova, G.S. 2017. Competitiveness of the national insurance market in the conditions of integration of the Eurasian Economic Union. Karaganda.182p.

Serikova, G.S. 2015. On the development of the insurance market of the Republic of Kazakhstan. International Scientific Journal "Symbol of Science", 6(13): 147-149.

Shekhovtseva, A. 2015. Competitiveness of the region: factors and method of creation. Marketing in Russia and abroad, 4(9): 11-15.

Spletukhov, Yu.A. 2015. Regulation of insurance activity in the EAEU countries: similarities and differences. Research Financial Institute. Financial Journal, 3(11): 86-90.

Spletukhov, Yu.A., Dyuzhikov, E.F. 2015. Indicators of the analysis of the financial condition of the insurance organization. Auditor, 6(34): 31-33.

US Competitiveness in the World Economy. 1985. Boston: Harbard Business SchooL Press. 14-16.

Vasilieva, Z.A. 2016. The hierarchy of concepts of competitiveness of market entities. Marketing in Russia and abroad, 2(24): 10-12.

Vorotnikov, A. 2016. Strategies to increase the competitiveness of the region. Economic strategies, 6(11): 144-149.

Zhuk, I.N. 2015. Competitiveness of the insurance company as an object of management. Insurance business, 5(11): 78-82. 


\section{ENTREPRENEURSHIP AND SUSTAINABILITY ISSUES}

ISSN 2345-0282 (online) http://jssidoi.org/jesi/ 2019 Volume 7 Number 1 (September)

http://doi.org/10.9770/jesi.2019.7.1(50)

\section{Aknowledgements}

This research was supported by the project, which has received funding from the Kazakhstan Ministry of Education and Science under the grant of "Best teacher of the university - 2018" http://edu.gov.kz/m/news/detail.php?ELEMENT_ID=11522

Gulzira SERIKOVA is Candidate of Economic Sciences, Professor of Karaganda Economic University of Kazpotrebsoyuz, Karaganda, Kazakhstan. Research interests: finance, insurance, banks.

ORCID ID: orcid.org/0000-0001-9013-7059.

Yerkenazym ORYNBASSAROVA is PhD, Associate Professor of Karaganda Economic University of Kazpotrebsoyuz, Karaganda, Kazakhstan. Research interests: investment, innovation, human resources.

ORCID ID: orcid.org/0000-0002-5577-6434

Svetlana KUZGIBEKOVA is Candidate of Economic Sciences, Associate Professor of Karaganda Economic University of Kazpotrebsoyuz, Karaganda, Kazakhstan. Research interests: financial aspects of economic development, investment, lending; financing of the economy, development of banking system, problems of functioning of country's financial system.

ORCID ID: orcid.org/0000-0003-2517-8908

Zeinegul YESSYMKHANOVA is Doctor of Economic Sciences, Professor of Karaganda Economic University of Kazpotrebsoyuz, Karaganda, Kazakhstan. Research interests: housing financing, development of mortgage lending, investments, banking system problems

ORCID ID: orcid.org/0000-0001-5552-5849

Galiya TATIYEVA is Candidate of Economic Sciences, Associate Professor of Turan University, Astana, Kazakhstan Research interests: role of financial and credit organizations in ensuring economic growth, development of banking system, mobilization of financial and credit resources

ORCID ID: orcid.org/0000-0002-0715-2432

Ainura OMAROVA is PhD, Associate Professor of Karaganda Economic University of Kazpotrebsoyuz, Karaganda, Kazakhstan. Research interests: investment, innovation, human resources.

ORCID ID: orcid.org/0000-0001-9808-4908

Copyright (C) 2019 by author(s) and VsI Entrepreneurship and Sustainability Center

This work is licensed under the Creative Commons Attribution International License (CC BY).

http://creativecommons.org/licenses/by/4.0/

(c) (7) Open Access 